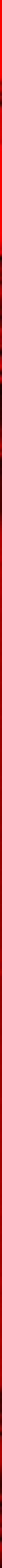

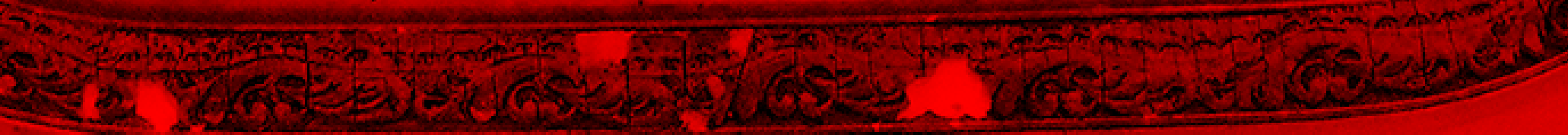

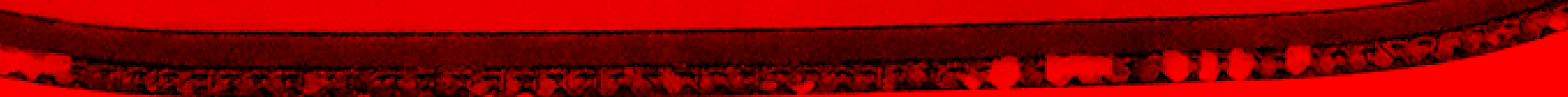




\section{Por uma moda (po)ética}

\section{Valéria Faria dos Santos Tessari - Editora executiva http://orcid.org/0000-0002-7959-909X}

Maria Claudia Bonadio - Editora-chefe

https://orcid.org/0000-0001-9704-9780

Uma nova edição da dObra[s] está no ar e traz novidades! Agora a revista está no Instagram (@dobrasrevista), rede na qual circulará informações sobre o conteúdo das edições atual e anteriores, chamadas para publicações e notícias. Além disso, a partir desta edição, passamos a contar com a colaboração de Carina Borges Rufino em nossa equipe, a quem damos boas-vindas.

Muito bem-vindo também é o tema do dossiê. 0 necessário e urgente Moda ética, um novo olhar sobre o novo foi organizado pelas pesquisadoras doutoras Lilyan G. Berlim, da Escola Superior de Propaganda e Marketing (Rio de Janeiro) e Neide Schulte, da Universidade do Estado de Santa Catarina (Florianópolis). Nesse conjunto de textos, autoras e autores abordam algumas das transformações que estão em curso nas práticas de produção, na circulação e no consumo de moda em direção a formas mais sustentáveis e que tenham a vida humana e a do planeta no centro de suas preocupações. Os textos apontam ainda transformações necessárias e futuras, imaginadas e sonhadas, que clamam por atitudes a fim de serem materializadas.

0 encontro desses artigos com as imagens da edição não poderia ser mais feliz. As fotografias revelam o trabalho dos amantes da moda e sonhadores Alexandre Linhares e Thifany F., da marca H-AL (@halartetextil), de Curitiba (PR). Alexandre e Thifany são os produtores e os curadores das imagens e as apresentam por meio de uma carta endereçada a todas, todos e todes - De H-AL para dObra[s] - na qual compartilham histórias sobre as roupas, o trabalho e as pessoas retratadas, que constituem seu ofício e sua vida. Aliás, tal presença nesta edição tem um motivo muito nítido: o modo como escolheram trabalhar/viver, com desperdício zero e muitas emendas, fazendo roupas com uma (po)ética própria e inspiradora.

Seguindo as páginas, apresentamos o texto de Lilyan G. Berlim, Contribuições para a construção do conceito do slow fashion: um novo olhar sobre a possibilidade da leveza sustentável, na seção Costuras. Esse artigo é uma versão revista e ampliada de publicação anterior ${ }^{1}$, no qual a autora aprofunda e amadurece temas constantes em sua trajetória de pesquisa.

Os textos que compõem a seção Artigos são os que nos chegaram em fluxo contínuo e podem ter a leitura sensibilizada pelo tema abordado no dossiê, uma vez que tratam de

\footnotetext{
${ }^{1}$ A saber, Slow Fashion, soluções práticas e ideológicas para novos tempos, I Congresso Ibero-Americano de Economia Criativa da ESPM, Rio de Janeiro, novembro de 2020.
} 
questões relacionadas a produção, circulação e consumo de moda que são, necessariamente, atravessadas pelas implicações da ética e da sustentabilidade.

Discutindo aspectos do circuito vigente da produção da moda, Amanda Queiroz Campos trata em "Eu não sigo tendência": o uso e o não-uso de relatórios de tendências de moda por designers no Brasil e na Alemanha como empresas utilizam ou não - e como narram tais usos - os guias de tendências produzidos por bureaux de style, inserindo-se, desse modo, nas práticas organizadas ao redor de um calendário comum de lançamento de coleções.

Em A review on potential technological advances for fashion retail: smart fitting rooms, augmented and virtual realities, Clara Fernandes e Ricardo Morais abordam como novas tecnologias podem permitir inclusão tanto de pessoas como de novas práticas de consumo, facilitando o acesso e a experiência da compra por meio de dispositivos inteligentes.

Carolina Santos Garcia, no texto Lojas Marisa: a promessa do preço baixo nas vitrinas da avenida Paulista, reflete sobre como significados relacionados ao consumo de moda por parte de grupos sociais populares foram reconstruídos e transformados nas Lojas Marisa por meio da unidade localizada estrategicamente na avenida Paulista, em São Paulo.

Abordando práticas de criar e produzir vestimentas, Manita Menezes e Marcos Beccari discutem, em A moda e a teoria queer: o unissex e o gênero neutro, como produtos de moda identificados como unissex ou de gênero neutro são materializados, e como esse tipo de produto pode vir a se configurar como modo de emergência de novos sujeitos e espaços para a inclusão.

Processos de criação de produtos também são o tema de Serpente: ornamento que transcende a materialidade das joias, no qual Gina Rocha Reis Vieira aponta os sentidos da imagem da serpente utilizada na criação de joias e ornamentos corporais, e esboça um exercício de criação de produto a partir de suas pesquisas.

Assim como inúmeros aspectos e setores da vida humana, a moda também é atingida pela avassaladora pandemia atual, o que está marcado nos dois textos seguintes. Em Atravessamentos interculturais em tempos de covid-19: a máscara como adorno da sobrevivência indígena, Indyanelle Marçal Garcia Di Calaça e Rita Morais de Andrade explicitam práticas de criação e produção de máscaras de tecido com grafismos próprios da Associação das Mulheres Indígenas Sateré Mawé. As autoras compreendem essas realizações como estratégia de sobrevivência contra a covid-19, mas também contra a marginalização histórica dos povos indígenas.

0 texto Competências empreendedoras mandatórias para o enfrentamento de um ambiente de crise: uma análise no setor da moda fluminense, de Luiza Silva Calado, Daniel Kamlot e Veranise Jacubowski Correia Dubeux, encerra a sequência de artigos. Nele, as autoras e o autor investigam e registram as principais competências empreendedoras que permitiram a manutenção de pequenos negócios de moda no Estado do Rio de Janeiro, durante as recentes crises financeiras e a pandemia de covid-19 em curso. 
Na seção Resenhas, Sandra Regina Rech apresenta-nos a exposição Memos. A proposito della moda in questo millennio, realizada no Museu Poldi Pezzoli, em Milão, na Itália, entre fevereiro e setembro de 2020. Em O poder narrativo da moda em cinco palavras, a autora informa que a exposição foi criada pela curadora Maria Luisa Frisa a partir da obra de Ítalo Calvino, Lezioni americane: sei proposte per il prossimo millennio, para pensar se a moda pode ser entendida como uma prática científica e poética.

Encerramos a edição com a seção Galeria, na qual as imagens da H-AL podem ser apreciadas acompanhadas de legendas.

Agradecemos profundamente todas, todos e todes que trabalharam na produção deste número. Às organizadoras do dossiê, às e aos pareceristas, aos produtores/curadores das imagens e à equipe da dObra[s], que atuaram voluntariamente para viabilizar a publicização do conhecimento e a abertura de diálogos, criando espaços para o questionamento de práticas vigentes na moda e oferecendo outras perspectivas.

Boa leitura! 